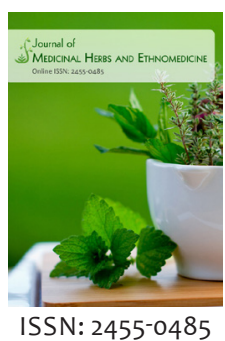

Received: July 03, 2019 Accepted: February 20, 2020 Published: March 11, 2020

*Corresponding Author: E. M. Isikhuemen Email: ekeoba.isikhuemen@ uniben.edu

\section{Host specificity and phytochemical constituents of mistletoe and twigs of parasitized plants: Implications for blanket application of mistletoe as cure-all medicine}

\author{
E. M. Isikhuemen*, U. O. Olisaemeka, G. O. Oyibotie \\ Department of Forest Resources and Wildlife Management, Faculty of Agriculture, University of Benin, Benin City, \\ Nigeria
}

\begin{abstract}
A study on host specificity and phytochemical constituents of leaves of mistletoe and parasitized twigs of seven host trees/shrubs was conducted in University of Benin, Benin City, Nigeria. Plant height and location were measured with Nikon Laser Rangefinder (Forestry 550) and GPS respectively while occurrence and count of mistletoe on host plants was largely anecdotal/visual. Phytochemical analyses were conducted at Faculty of Agriculture Science/Soil Laboratory, University of Benin, Benin City, Nigeria while data were subjected to One-way Analysis of Variance and means separated using Duncan Multiple Range Test $(\mathrm{p}=0.05)$. Results revealed mistletoe were largely generalists, and contained more phytochemicals than host plants. Tapinanthus ogowensis from Moringa oleifera was richest in alkaloid; Phragmanthera nigritana on Citrus sinensis, Tapinanthus ogowensis on Moringa oleifera and Phragmanthera capitata on Calliandra portoricensis recorded highest phenol content and differences among them were not significant $(\mathrm{p}<0.05)$. Phragmanthera capitata on Spondias mombin had significantly higher tannins than other mistletoe and host plants $(\mathrm{p}<0.05)$. P. capitata on S. mombin recorded best for saponin and flavonoid while P. capitata on Psidium guajava, Loranthus micranthus on Persia americana and P. capitata on C. portoricensis recorded more anthraquinone and were not significantly different from each other $\mathrm{p}<0.05$. While the marked variation in phytochemicals in leaves of mistletoe and twigs of host plants is noteworthy; the study has sufficiently established that ecological idiosyncrasies, time/season and varied environmental phenomena strongly influence incidence and/or buildup of secondary metabolites. The foregoing should serve as benchmark in selection and/or use of mistletoe for resolving infirmities.
\end{abstract}

KEYWORDS: Mistletoe, ethnomedicine, generalists, host preference, parasitized plants, phytochemicals

\section{INTRODUCTION}

Host specificity is the restricted use of available potential host species at a local scale, while host preference refers to the hierarchical ranking of host use [1]. Several factors such as seed dispersal vectors, host availability, host abundance, host compatibility and suitable niche for the parasite determine host specificity in mistletoes [2]. Mistletoe are hemiparasitic plants which access water and nutrients from other living plants [3]. They physically attach at least one point either to the above ground (aerial/stem/shoot parasites) or below ground (root parasites) parts of the host plants [4]). As hemi-parasites that parasitize and obtain nourishment from the branches of trees/ shrubs with the aid "haustoria", mistletoe possess chlorophyll and photosynthesize but the quantum of nutrients and water they obtain from their host plants tend to vary in relation to host use preference and/or specificity [5,6,7]. The term 'host specificity' is used to connote the restricted use of available potential host species at a local scale, host preference refers to the hierarchical ranking of host use [1].

In Africa, $70 \%$ of mistletoe are generalist species, that is, species that parasitize hosts from several families; $12 \%$ are specific on hosts from one family but occasionally parasitize a few genera of other families and $18 \%$ are specific to one or a few host species of a single genus [8]. A number of mistletoe species are specialized in living on different hosts due to frequent encounters between mistletoe seeds and commonest plants [9]. Tizhe et al [10]

Copyright: $\odot$ The authors. This article is open access and licensed under the terms of the Creative Commons Attribution License (http://creativecommons.org/licenses/by/4.0/) which permits unrestricted, use, distribution and reproduction in any medium, or format for any purpose, even commercially provided the work is properly cited. Attribution - You must give appropriate credit, provide a link to the license, and indicate if changes were made. 
reported that mistletoe could parasitize a variety of tree species with few of them having special preference to certain type of host plants. Some studies have indicated that non-random perch preferences of seed dispersers are important for determining host specificity [11]. This may result in concentration of mistletoe seeds on either the most abundant trees or the less abundant ones [9].

As semi-parasitic plants, mistletoe are considered as unwanted plant but are also known for their medicinal value and use in the treatment of various ailments including cough, diabetes, cancer, ulcer, etc. $[12,13]$. Mistletoe are now known as "cure all" and have been used as a drug/remedy for more than twenty health problems [14]; this is dependent on the phytochemicals they contain and the efficacy of drug produced which are linked to the host plant(s) and that mistletoe harvested there from, are suited for the treatment or cure of ailments [15]. Dibong et al [16] reported that $82 \%$ of the healers in a region in Cameroon recommended Phragmanthera capitata for the treatment of some 22 different diseases, including hypertension, hypotension, irregular menstruations, menopause, convulsions, diabetes, rheumatism related pains, epilepsy, kidney and chronic muscular pains. This may not have a scientific backing as constituents of Korthalsella japonica did not change or disappear irrespective of its host trees [17].

Host specificity is an elusive concept and the mechanism behind it remains one of the most challenging areas of mistletoe biology [18]. These aerial parasites have received little research attention compared to their counterparts - the root parasites $[19,20]$. There is lot of confusion regarding the taxonomy of Loranthaceae, particularly in West Africa; for example, in Nigeria, many authors have referred to most Tapinanthus spp. as V. album, a foreign plant that does not occur in the country [21]. Some people often identify mistletoe through the host plant it is found on; this can be very misleading as different mistletoe species could grow on a particular tree host or vice versa [22].

The phytochemical constituents of mistletoe largely depend on plant characteristics, season of the year, mode of extraction, etc. Using 'methanolic extract of the leaves harvested from Persea americana, Moghadamtousi et al. [23] recorded higher concentrations of alkaloids during April compared to July which is the peak of raining season; but saponins, glycosides, etc. were not found in July samples. But Osadebe et al. [24] recorded higher amounts of flavonoids and oils in July compared to April samples. Phytochemical studies on Loranthus micranthus leaves harvested from six different host trees, namely, Persia americana, Baphia nitida, Kola acuminata, Pentaclethra macrophylla, Azadiratcha indica, and Irvingia gabonensis, revealed that alkaloids were in significant quantities in the extracts of K. acuminata, P. americana, and I. gabonensis; moreover, the phytochemical constituent host dependency was also shown $[13,25]$. A petroleum ether extract of $L$. micranthus leaves parasitic on P. americana harvested at different seasons (January, April, July, and November) showed only presence of alkaloids in April and July and proved harvesting period dependency in phytochemicals of L. micranthus [26].
In the light of the forgoing this paper evaluates host specificity / dependency and use preference alongside important secondary metabolites of medicinal relevance that mistletoe share with selected parasitized host trees/shrubs. The intertwining roles played by intrinsic (e.g. biological characteristics and idiosyncrasies of host and hemi-parasitic plants) and ecological/ environmental factors, particularly season, dispersal agents and phytochemical screening methods in shaping the presence and/or availability of secondary metabolites in mistletoe and parasitized plants are highlighted.

\section{METHODOLOGY}

\section{Study Area}

The study was carried out in University of Benin, Benin City, Edo State, Nigeria (Latitudes $6^{\circ} 11^{\prime}$ and $6^{\circ} 29^{\prime} \mathrm{N}$ and Longitudes $5^{\circ}$ $33^{\prime}$ and $5^{\circ} 47^{\prime} \mathrm{E} ; 109 \mathrm{~m}$ asl $)$. Benin City, the capital of Edo State, is located in the rainforest region of Nigeria. The Mean annual rainfall ranges from 1800 to $2000 \mathrm{~mm}$; mean relative humidity is about $75 \%$ at noon and $95 \%$ at the early hours of the day while the maximum and minimum temperatures averaged $330 \mathrm{C}$ and $230 \mathrm{C}$ respectively [27]. The general topography of Benin City typically low, sloping gently from about $105 \mathrm{~m}$ above sea level in the northeast to about $55 \mathrm{~m}$ above sea level in the south-west area [28].

\section{Materials and Methods}

Leaf and twig samples were collected from healthy plants with the aid of a sickle (go-to-hell) at various locations in University of Benin, Benin City, Nigeria in April, 2018. The height and positions of each sampled host tree/shrub were measured using Nikon Laser Rangefinder (Forestry 550) and geographical positioning system (GPS). The study on host specificity was field based and largely visual/anecdotal. Two sets of specimens were collected from the lower, middle and upper crown regions during the pre-mature to mature growth stages. One was primed for identification / authentication in the Forestry Research Institute of Nigeria (FRIN) herbarium at Ibadan (FHI) while the other was prepared (air dried, ground into uniform powder using a Thomas Willey milling machine before extraction, dehydration) for phytochemical screening at the Faculty of Agriculture crop and soil laboratory, University of Benin, Benin City, Nigeria.

\section{Tests for Secondary Metabolites}

The aqueous extract of each sample was prepared by soaking $100 \mathrm{~g}$ of dried powdered sample in $200 \mathrm{ml}$ of distilled water for $12 \mathrm{~h}$; and the extracts were filtered using Whatman filter paper No. $42(125 \mathrm{~mm})$ [29].

(a) Test for Alkaloid was carried out using methods described by Boham and Kocipai-Abyazan [30]: 20\% ethanol was added to $\mathrm{lg}$ of each extracted sample; allowed to stand for 2-4 hours and then filtered. Concentrated ammonium hydroxide was added to the extract to precipitate the alkaloid and the precipitate filtered, oven dried for $30 \mathrm{mins}$ at $60^{\circ} \mathrm{C}$ and reweighed. 
(b) Total Phenols were determined by spectrophotometric method [29]. The fat free sample was boiled with $50 \mathrm{ml}$ of ether for the extraction of the phenolic component for 15 minutes. $5 \mathrm{ml}$ of the extract was pipetted into a 50 $\mathrm{ml}$ flask, then $10 \mathrm{ml}$ of distilled water was added. $2 \mathrm{ml}$ of ammonium hydroxide solution and $5 \mathrm{ml}$ of concentrated amylacholol were added. The samples were made up to mark and left to react for $30 \mathrm{~min}$ for colour development and measurement was taken at $505 \mathrm{~nm}$.

(c) Test for Tannins was carried out using methods described by Van-Burden and Robinson [31] .lg of each of the sample was weighed and macerated with $50 \mathrm{ml}$ of distilled water. The mixture was filtered and $1 \mathrm{ml}$ of filtrate pipetted into test tubes. $2 \mathrm{ml}$ of the saturated picric acid was then added. Absorbance was measured at $530 \mathrm{~nm}$ and tannin acid $1.3 \%$ in $100 \mathrm{ml} \mathrm{H}_{2} \mathrm{SO}_{4}$.

(d) Saponin test followed methods described by Obadoni and Ochuko [32]. $20 \mathrm{~g}$ of ground sample was weighed into a conical flask and $100 \mathrm{~cm}^{3}$ of $20 \%$ aqueous ethanol added. It was heated over a hot water bath for $4 \mathrm{~h}$ while stirring continuously at about $55^{\circ} \mathrm{C}$ and the mixture was filtered and residue re-extracted with $100 \mathrm{ml}$ of $20 \%$ ethanol. Extracts were reduced to $40 \mathrm{ml}$ over water bath at about $90^{\circ} \mathrm{C}$ and the concentrate transferred into a $250 \mathrm{ml}$ separating funnel and $20 \mathrm{ml}$ of diethyl ether added and shaken vigorously. The aqueous layer was recovered and the ether layer discarded. The purification process was repeated; $30 \mathrm{ml}$ of n-butanol was added and the combined n-butanol extracts were washed twice with $10 \mathrm{ml}$ of $5 \%$ aqueous Sodium chloride. The solution was heated in a water bath; after evaporation, samples were dried in the oven to a constant weight at $60^{\circ} \mathrm{C}$ for $2 \mathrm{hrs}$ and the saponin content calculated as percentage.

(e) Test for Flavonoid followed Boham and KocipaiAbyazan [30]. $\mathrm{lg}$ of samples were extracted repeatedly with $100 \mathrm{ml}$ of $80 \%$ aqueous methanol at room temperature for 2 to 6hours while soaking and filtering. The whole solution was filtered through Whatman filter paper no 42 $(125 \mathrm{~mm})$. The filtrate was later transferred into a crucible and evaporated to dryness over water and weighed to a constant weight.

(f) Anthraquinone was determined by methods described by Soladoye and Chukwuma [33]. lg of extracted sample was soaked in $50 \mathrm{ml}$ distilled water for 16 hours. The suspension was heated in a water bath at $70^{\circ} \mathrm{C}$ for $1 \mathrm{~h}$ and allowed to cool. Few drops of $80 \%$ methanol was added to it and then filtered. The clear solution was then measured by an absorbance of $459 \mathrm{~nm}$.

(g) Cyanogenic glycoside determination: Methods described by Piero et al. [34] was used: $1 g$ of each plant sample was dispersed in $200 \mathrm{ml}$ of warm water and the suspension heated for $3 \mathrm{~h}$ while stirring continuously. The filtrate and residue were then re-extracted with $100 \mathrm{ml}$ acetone and reduced to $10 \mathrm{ml}$ on heating. The concentrate was then weighed and Cyanogenic glycoside content calculated.

\section{Data Analysis}

Data obtained from the phytochemical analysis of were arranged in a Completely Randomized Design (CRD) and subjected to Analysis of Variance (ANOVA) while the Duncan Multiple Range Test (DMRT) was used to separate the means $(\mathrm{p}=0.05)$.

\section{RESULTS}

\section{Profile of Parasitized Host Trees/Shrubs and Associated Mistletoe Species}

Fifty-two trees/shrubs distributed among seven species were parasitized by mistletoe in the study area. The profile of sampled plants, mistletoe and incidence on host plants and their locations are shown in Table 1.

\section{Phytochemical Constituents of Leaves of Mistletoe and Twigs of Trees/Shrubs}

Results revealed generally higher phytochemicals in the mistletoe than twigs of host plants. Overall, S. mombin twig and associated mistletoe were richest in three phytochemicals (saponin, tannins and flavonoid) and were significantly different from the rest plants $(p<0.05)$. The mistletoe associated with $M$. oleifera had best results for alkaloid while phenolic content was significantly higher in mistletoe obtained from C. sinensis, M. oleifera and C. portoricensis. Anthraquinone was richest in mistletoe obtained from $P$. guajava, $P$. americana and C. portoricensis while Cyanogenic glycoside was highest in mistletoe collected from M. oleifera (Table2).

\section{DISCUSSION}

Most mistletoe species recorded were characteristically not selective of, or specific to, any particular host; implying that the hemi-parasites were predominantly generalists. From results, $P$. capitata which parasitized four host trees and shrubs, namely S. mombin, P. americana, C. portoricensis and P. guajava, and T. ogowensis which infected M. oleifera and P. guajava. In an investigation conducted in Ghana Overfield et al. [35] found 'T. ogowensis to have infested a wide range of hosts such as Citrus spp. (Rutaceae), P. americana (Lauraceae), T. cocoa (Sterculiaceae) and C. nitida (Sterculiaceae).

The high incidence of $P$. nigritana recorded in one of the two orchards of C. sinensis encountered during the study portrayed the hemi-parasite as localized or specific. Dibong et al. [36] designated Globimetula opaca which parasitized C. sinensis in an orchard in the Duala region of Cameroon as site- and host-specific. This result is not in agreement with the results of investigations carried out on African mistletoe by several authors who worked in West and Central Africa. For example, in some studies conducted in Cameroon, Ghana and Nigeria $[15,36,37]$ several species of mistletoe, namely Globimetula spp. T. bangwensis, T. ogowensis, P. capitata, P. incana, T. globiferus) found in citrus orchards, were classified as 'generalists'.

The above findings aptly confirm that the mode of infestation of host plants by mistletoe was not overly restrictive. For example, the number and type of shrubs encountered during the study as host species (e.g., C. portoricensis, P. alba, P. guajava) and the 
Table 1: List of Parasitized Host plants and associated Mistletoe species

\begin{tabular}{|c|c|c|c|c|}
\hline $\begin{array}{l}\text { Scientific name \& } \\
\text { (Habit of plant) }\end{array}$ & Common name & Sample plant height $(\mathrm{m})$ & Mistletoe species (and incidence on host plant) & Position of tree/shrub \\
\hline $\begin{array}{l}\text { Calliandra } \\
\text { portoricensis (Shrub) }\end{array}$ & English Powder puff & 5.82 & Phragmanthera capitata (6) & $\begin{array}{l}\mathrm{N}^{0} 6^{\circ} 24^{\prime} 22^{\prime \prime} \\
\mathrm{E} 005^{\circ} 37^{\prime} 24^{\prime \prime}\end{array}$ \\
\hline Citrus sinensis (Tree) & Sweet Orange & 4.36 & Phragmanthera nigritana (8) & $\begin{array}{l}N 06^{\circ} 23^{\prime} 51^{\prime \prime} \\
E 005^{\circ} 37^{\prime} 35^{\prime \prime}\end{array}$ \\
\hline $\begin{array}{l}\text { Moringa oleifera } \\
\text { (Tree) }\end{array}$ & Moringa & 6.44 & Tapinanthus ogowensis (3) & $\begin{array}{l}N 06^{\circ} 24^{\prime} 24^{\prime \prime} \\
\mathrm{E} 005^{\circ} 37^{\prime} 26^{\prime \prime}\end{array}$ \\
\hline $\begin{array}{l}\text { Persea Americana } \\
\text { (Tree) }\end{array}$ & Avocadopear & 7.25 & Phragmanthera capitata; Loranthus micranthus (6) & $\begin{array}{l}N 06^{\circ} 24^{\prime} 23^{\prime \prime} \\
\mathrm{E} 005^{\circ} 37^{\prime} 12^{\prime \prime}\end{array}$ \\
\hline $\begin{array}{l}\text { Plumeria alba } \\
\text { (Shrub/Small tree) }\end{array}$ & Frangipani & 4.83 & Tapinanthus ogowensis (4) & $\begin{array}{l}N 06^{\circ} 24^{\prime} 22^{\prime \prime} \\
\text { E005 }^{\circ} 37^{\prime} 10^{\prime \prime}\end{array}$ \\
\hline $\begin{array}{l}\text { Psidium guajava } \\
\text { (Shrub/Small tree) }\end{array}$ & Guava & 3.75 & Phragmanthera capitata (3) Tapinanthus ogowensis (3) & $\begin{array}{l}\mathrm{N} 06^{\circ} 24^{\prime} 18^{\prime \prime} \\
\mathrm{E} 005^{\circ} 37^{\prime} 36^{\prime \prime}\end{array}$ \\
\hline $\begin{array}{l}\text { Spondias mombin } \\
\text { (Tree) }\end{array}$ & Hog plum & 12.93 & Phragmanthera capitata (9) & $\begin{array}{l}N 06^{\circ} 23^{\prime} 50^{\prime \prime} \\
E 005^{\circ} 37^{\prime} 33^{\prime \prime}\end{array}$ \\
\hline
\end{tabular}

Table 2: Assortment of secondary metabolites in leaves of mistletoe species and twigs of host plants

\begin{tabular}{|c|c|c|c|c|c|c|c|c|}
\hline Phytochemical & Source & P. alba & S. mombin & C. sinensis & M. oleifera & C. portoricensis & P. americana & P. guajava \\
\hline \multirow[t]{2}{*}{ Alkaloid } & $\mathrm{H}$ & $0.772 \pm 0.028^{\mathrm{cd}}$ & $1.274 \pm 0.033^{a}$ & $1.162 \pm 0.037^{b}$ & $1.134 \pm 0.001^{b}$ & $0.742 \pm 0.001^{d}$ & $0.830 \pm 0.002^{c}$ & $0.597 \pm 0.033^{e}$ \\
\hline & M & $1.676 \pm 0.048^{c}$ & $1.573 \pm 0.001^{\mathrm{d}}$ & $1.745 \pm 0.001^{b}$ & $1.842 \pm 0.001^{\mathrm{a}}$ & $1.135 \pm 0.001^{\mathrm{g}}$ & $1.218 \pm 0.003^{f}$ & $1.321 \pm 0.002^{\mathrm{e}}$ \\
\hline \multirow[t]{2}{*}{ Phenol } & $\mathrm{H}$ & $0.431 \pm 0.005^{c}$ & $0.416 \pm 0.001^{c}$ & $0.532 \pm 0.001^{\mathrm{d}}$ & $0.629 \pm 0.004^{a}$ & $0.527 \pm 0.004^{b}$ & $0.646 \pm 0.006^{a}$ & $0.559 \pm 0.031^{b}$ \\
\hline & M & $0.682 \pm 0.006^{d}$ & $0.755 \pm 0.043^{c}$ & $1.076 \pm 0.003^{\mathrm{a}}$ & $1.034 \pm 0.001^{\mathrm{a}}$ & $1.012 \pm 0.001^{\mathrm{a}}$ & $0.859 \pm 0.040^{b}$ & $0.820 \pm 0.001^{b c}$ \\
\hline \multirow[t]{2}{*}{ Tannin } & $\mathrm{H}$ & $0.527 \pm 0.068^{e}$ & $1.225 \pm 0.001^{a}$ & $1.124 \pm 0.001^{a}$ & $0.859 \pm 0.042^{c}$ & $0.673 \pm 0.001^{d}$ & $1.024 \pm 0.001^{b}$ & $1.159 \pm 0.025^{a}$ \\
\hline & M & $1.039 \pm 0.004^{\mathrm{e}}$ & $1.428 \pm 0.003^{a}$ & $1.264 \pm 0.027^{c}$ & $1.114 \pm 0.001^{d}$ & $0.829 \pm 0.003^{f}$ & $1.288 \pm 0.025^{c}$ & $1.365 \pm 0.001^{b}$ \\
\hline \multirow[t]{2}{*}{ Saponin } & $\mathrm{H}$ & $0.285 \pm 0.035^{\mathrm{e}}$ & $0.732 \pm 0.003^{a}$ & $0.412 \pm 0.001^{b c}$ & $0.357 \pm 0.001^{c d}$ & $0.381 \pm 0.032^{\mathrm{bcd}}$ & $0.432 \pm 0.001^{b}$ & $0.336 \pm 0.002^{\mathrm{de}}$ \\
\hline & M & $0.640 \pm 0.002^{\mathrm{e}}$ & $1.016 \pm 0.001^{a}$ & $0.748 \pm 0.031^{d}$ & $0.888 \pm 0.027^{b}$ & $0.827 \pm 0.004^{c}$ & $0.909 \pm 0.019^{b}$ & $1.022 \pm 0.001^{a}$ \\
\hline \multirow[t]{2}{*}{ Flavonoid } & $\mathrm{H}$ & $0.461 \pm 0.043^{b}$ & $0.717 \pm 0.001^{\mathrm{a}}$ & $0.252 \pm 0.001^{c}$ & $0.216 \pm 0.001^{c}$ & $0.133 \pm 0.003^{d}$ & $0.103 \pm 0.001^{\mathrm{d}}$ & $0.126 \pm 0.001^{\mathrm{d}}$ \\
\hline & $M$ & $0.716 \pm 0.004^{b}$ & $1.134 \pm 0.001^{\mathrm{a}}$ & $0.546 \pm 0.012^{c}$ & $0.564 \pm 0.036^{c}$ & $0.422 \pm 0.003^{d}$ & $0.578 \pm 0.032^{c}$ & $0.515 \pm 0.001^{c}$ \\
\hline \multirow[t]{2}{*}{ Anthraquinone } & $\mathrm{H}$ & $0.342 \pm 0.048^{d}$ & $0.236 \pm 0.001^{\mathrm{e}}$ & $0.328 \pm 0.001^{d}$ & $0.419 \pm 0.001^{c}$ & $0.522 \pm 0.001^{b}$ & $0.422 \pm 0.003^{c}$ & $0.568 \pm 0.002^{\mathrm{a}}$ \\
\hline & $M$ & $0.370 \pm 0.024^{d}$ & $0.440 \pm 0.006^{c}$ & $0.521 \pm 0.005^{b}$ & $0.557 \pm 0.035^{b}$ & $1.014 \pm 0.001^{\mathrm{a}}$ & $1.035 \pm 0.001^{\mathrm{a}}$ & $1.042 \pm 0.005^{\mathrm{a}}$ \\
\hline \multirow{2}{*}{$\begin{array}{l}\text { Cyanogenic. } \\
\text { glycoside }\end{array}$} & $\mathrm{H}$ & $0.042 \pm 0.001^{b}$ & $0.036 \pm 0.001^{c}$ & $0.105 \pm 0.002^{\mathrm{a}}$ & $0.013 \pm 0.001^{\mathrm{e}}$ & $0.014 \pm 0.001^{\mathrm{e}}$ & $0.012 \pm 0.001^{\mathrm{e}}$ & $0.021 \pm 0.001^{d}$ \\
\hline & M & $0.112 \pm 0.002^{\mathrm{d}}$ & $0.214 \pm 0.001^{b}$ & $0.114 \pm 0.001^{\mathrm{d}}$ & $0.303 \pm 0.002^{\mathrm{a}}$ & $0.014 \pm 0.002^{\mathrm{e}}$ & $0.015 \pm 0.002^{\mathrm{e}}$ & $0.204 \pm 0.001^{c}$ \\
\hline
\end{tabular}

Means $(a, b, c, d, e, f, g)$ with different superscript along row are significantly different $(p \leq 0.05) ; H=$ Host plant twig; $M=M$ istletoe

number and occurrence of hemi-parasites in each plant palpably confirm that "for any mistletoe to transform from generalist to specialist and vice versa, some salient factors, including abundance/diversity of host species, the dispersing agent's ability to encounter preferred host, etc. were likely to come into play. Some authors $[1,38]$ have argued that 'host choice can be considerably influenced by host abundance'; while others [39] asserted that "mistletoe are found to be generalists in places with high host species diversity".

Several authors $[1,10,38]$ have made allusions to the fact that host abundance often exerts a strong influence on parasitization by mistletoe species. But the findings in this study appear to be at variance with the authors' assertion because two tree species encountered in the study area, Azadirachta indica and Delonix regia, though abundant, but were not parasitized. Additionally, of the four stands of C. portoricensis and P. alba assessed, only one stand each was parasitized while infestation incidence was six and four respectively. Downey [40] has argued that host selection favours close physiological adaptations of the mistletoe. But Fadini [9] opined that host specificity depends on host abundance as well as compatibility at the physiological, genetic, mechanical and biochemical levels. While one is at liberty to reason that both A. indica and D. regia, lacked the physiological adaptation to attract mistletoe that parasitized other host trees; to what could the absence of mistletoe on the remaining three stands of C. portoricensis and P. alba, which very close to each other, be ascribed? Some authors $[11,41]$ have contended that mistletoe specialization on trees is not dependent on frequent encounter of mistletoe seeds and host trees. This may rather be explained by non-random perch preferences of dispersal birds which could result in the concentration of seeds on both most abundant and less abundant tress $[42,43]$.

Some important factors that might have influenced specificity or specialized infestation of hosts by mistletoe in the study area were abundance, diversity and/or assortment of cultivated fruit, ornamental and amenity tree/shrub species. According to Fadini [9], 'a number of mistletoe species are specialized in living on different hosts due to frequent encounters between mistletoe seeds and commonest plants'. This may result in concentration of mistletoe seeds on either the most abundant trees or the less abundant ones [9]. For example, Burkill [44] found Tapinanthus bangwensis on 43 different hosts in 18 plant families; while Pattanayak and Sunita [45] reported that Dendrophthoe falcata - the most common of all the mistletoe that occur in India -was associated with about 401 plant hosts.

From study results, plant height and crown size seemed to have significantly influenced the prevalence of mistletoe on some of 
the parasitized trees in the study area. For example, the tallest host tree, Hog plum (height: $12.93 \mathrm{~m}$ ) which also had the largest crown recorded the highest incidence/concentration of mistletoe species. This result is in agreement with the findings of Didier et al. [46] who reported that "host characteristics such as branch size, age and height and the duration of association between the host and the parasite affect prevalence. Tree height is an important host characteristic that controls mistletoe distribution and abundance; taller trees tend to attract more dispersers of mistletoe compared to shorter trees [42,47]. But Tizhe et al. [10] claimed that factors like abundance of host plants and vulnerability (characteristics) of the host plant could play a pivotal role in the parasitization of plant by mistletoe. Overton [48] also reported that 'characteristics such as branch size, age, and height of a host plant can have a strong influence on mistletoe attachment resulting in size related mistletoe infection patterns'.

The outcomes of phytochemical analyses revealed that mistletoe and twigs of associated host plants had significant amounts of all the phytochemicals investigated. The presence of these chemicals in the host plants might have acted as Haustorium Inducing Factors (HIFs), which aided in attracting these hemiparasites as the presence of HIFs such as phenols, flavonoid, etc. in the host plants may have in turn helped to initiate the development of haustorium [49]. While making reference to earlier findings on 'correlation between host and chemical profiles of the plant and parasite' many authors $[43,50,51,52]$ surmised that "the influence of host chemistry on the chemical constituent of the parasite on different hosts might justify why the host is as important as the parasite in ethnomedicine and why the use of mistletoe in the treatment of ailment is often dependent on a particular or specific host".

Hemi-parasitic plants can trigger salt imbalance leading to a concomitant reduction of salt content in parasitized host branches/twigs. Dibong et al. [53] investigated the influence of $P$. capitata on the distribution of sodium and potassium salts in the plant tissues five host species (Citrus maxima, Manikara zapota, P. americana, P. guajava and Theobroma cacao) and found that $\mathrm{P}$. capitata reduced the $\mathrm{Na}+$ concentrations in the aerial parts of infected host trees and maintained the salt level low in photosynthetic organs. The authors also observed high concentrations of $\mathrm{K}+$ in the leaves of the non-infected host branches of three hosts, C. maxima, M. zapota and P. guajava and concluded that Loranthaceae could contribute to decrease the content of salt on parasitized host boughs and then on branches bearing fruits. The fact that the mistletoe species found in this study recorded more phytochemicals than the twigs of their hosts might presumably be due to their hemiparasitic characteristics as suggested by Williams [54].

The similarity between phytochemicals contained in mistletoe and associated host plants have been highlighted in several past studies. For example, like its hemi-parasites, S. mombin has high extractable phenolic, saponins, tannin and anthraquinone contents $[55,56]$. The anti-malarial activity of S. mombin may be linked to a range of compounds like anthraquinones, berberine, flavonoids, naphthoquinones, sesquiterpenes, quassiniods, indole and quinoline alkaloids [57].This is because the efficacy of drugs are thought to be dependent on the host plant(s) and that mistletoes harvested on certain hosts are suited for the treatment or cure of a particular health problem [15]. Ayoka et al. [58], citing different authorities, chronicled the medicinal uses of $\mathrm{S}$. mombin and by implication the mistletoe associated with it to include: abortifacients [59, 60]; anti-epileptic and anti-psychotic [61]; anti-viral [62]; anti-ageing [63, 64]; antibacterial [62,65]; anti-diarrhoea [59]; anti-fertility [66]; antihelminthic [67]; anti-inflammation [68]; anti-malarial [57]; anti-microbial [56, 62]; anti-oxidant [64] and anxiolytic [69].

C. portoricensis leaves contain saponins, tannins, flavonoids and glycosides [70]. Numerous pharmacological activities have been reported, including anti asthmatic [71]; hypolipidaemic, erythropoietic [72], anti-sickling [73], anticonvulsant [74, 75] anthelmintic [70], antimicrobial as well as traditional management of sickle cell anaemia and prostate cancer in Africa[71], and analgesic [76,77].

The contention that presence or accumulation of secondary metabolites in mistletoe depend on the season of the year, mode of extraction of secondary metabolites as well as mistletoe - host plant dependency $[23,24]$ was accentuated as T. ogowenisis from M. oleifera recorded highest amount of alkaloids. Phytochemical studies on L. micranthus leaves harvested from six different host trees, namely, Persia americana, Baphia nitida, Kola acuminata, Pentaclethra macrophylla, Azadiratcha indica, and Irvingia gabonensis, revealed large quantities of alkaloids in the extracts of K. acuminata, P. americana, and I. gabonensis. Several authors $[13,25]$ have alluded to the strong relationships and phytochemicals - host dependency influence commanded by some fruit trees/shrubs. A petroleum ether extract of $L$. micranthus leaves parasitic on P. americana harvested at different seasons (January, April, July, and November) showed only presence of alkaloids in April and July and proved harvesting period dependency in phytochemicals of L. micranthus [26]. In a separate study, Ibrahim et al. [52] found no Alkaloids in all 27 mistletoe representing seven different species obtained from different locations spread across eight cities/towns in Nigeria palpably confirms the findings in this study and several others $[13,23,24,25,26]$.

All the mistletoe and host plants encountered in this study were found to have reasonable quantities of alkaloids. Alkaloids, the most valued of all the phytochemicals, are said to be pharmacologically active and their actions are felt in the autonomic nervous system, blood vessels, promotion of diuresis, respiratory system, gastrointestinal tract, uterus, malignant diseases, infections and malaria [78, 79]. Alkaloids are known to possess antimicrobial, anti-HIV and anti-parasitic abilities [80]. It has also been reported that alkaloids have anti-depressantlike actions in rodents [81]. Trease and Evans [82] and Madziga et al. [83] surmised that, "plants containing alkaloids do not feature strongly in herbal medicine as they are toxic".

Results on anthraquinone revealed that the mistletoe, P. capitata and T ogowensis from Guava recorded best followed by P. capitata and L. micranthus from Avocado pear and then 
P. capitata from English Powder-puff; and they were significantly different $(\mathrm{p}<0.05)$ from the rest results. These parasitic plants would be more suitable in the treatment of constipation, malaria and cancer $[84,85]$. The mistletoe, P. capitata, obtained from Spondias mombin and T. brameus collected from Plumeria alba were richest in flavonoid content. Flavonoid have been described as potent water-soluble antioxidants and free radical scavengers, which prevent oxidative cell damage and it does contain strong anticancer activity [86]. They are known to have a wide range of biological and pharmacological activities anti-inflammatory, anti-oxidant, anti-microbial and anti-cancer properties [87,88]. Halilu et al. [89]) reported the presence of Flavonoids, Saponnins, Cardiac glycosides in the mistletoe Tapinanthus globiferus but found anthraquinones and alkaloids absent, although present in the associated M. oleifera leaves.

The mistletoe, Phragmanthera capitata, collected from Spondias mombin during the study had the highest tannin content. Tannins are widely distributed through the plant kingdom which consists of anticancer properties by blocking the production of enzyme required for cancer cell line growth [90], and possess anti-oxidant properties which have the capacity to protect the tissues from the action of free radicals due to the cellular aging processes [91]. Tannins are also known for their anticancer properties and their usefulness in the protection of the urinary tract, cardiovascular and immune system [92]. Tannins have stringent properties, and hasten the healing of wounds and inflamed mucous membranes [93]. Tannins are a major phenolic compounds that act as primary antioxidant or free radical scavengers [94].

Saponin, recorded highest in P. capitata and T. ogowensis collected from P. guajava. Saponin is a secondary metabolite having medicinal properties such as anti-tumor properties; helps maintain blood cholesterol level and can be used as adjuvant in vaccines $[95,96]$. It has the precipitating properties and coagulating properties on red blood cells [86]; lower the cholesterol level and equipped with anti-diabetic and anticarcinogenic properties [78]. Adodo [14]) reported that the mistletoe associated with guava cure cancer.

The mistletoe, P. nigritiana, obtained from C. sinensis M. oleifera and $C$. portoricensis recorded highest phenolic content and were significantly different $(\mathrm{p}>0.05)$ from those associated with $P$. americana and P. guajava. Asami and Danny [97] asserted that phenol has anti-oxidant protection against heart disease and cancer and it also possesses anti-inflammatory ability. Like other phytochemicals, the phenol recorded in the mistletoe, P. nigritiana, was higher that what was obtained from the twig of Citrus. These results are in accord with earlier investigations by scientists $[98,99]$ who reported that "high amounts of phenol have long been known to be a phytochemical feature of parasitic flowering plants and they are said to occur at a level that is generally higher than their host plant".

The T. ogowensis obtained from Moringa oleifera was richest in cyanogenic glycoside. Cyanogenic glycoside is toxic and poses a potential risk to consumers [100]. Consequently, it has to be consumed in very low quantity, as its intake may lead to growth retardation especially if the protein intake of an individual is low; this is because detoxification of cyanide in human body requires sulfur donors from sulfur-containing amino acids [101]. Detoxification of cyanide in the human body can only be done if low level of cyanide is generated and this is only possible if a small amount of cyanide is consumed [100]. The fact that Cyanogenic glycoside was richest in T. ogowensis obtained from Moringa oleifera is an apt signal that the selection and use of host plant and associated mistletoe in ethnomedicine should be done with utmost caution.

\section{CONCLUSION AND RECOMMENDATION}

Mistletoe can be generalists or host specific; but host specificity and presence or accumulation of secondary metabolites and by extension, the potency of mistletoe/host plants as remedy for the treatment of ailments are a function of diverse inherent and external factors, including features of host plant (e.g. abundance, diversity, height, age, diameter and compatibility), season, agent and pattern of dispersal, screening methods, etc. The results of phytochemical composition revealed marked variations in secondary metabolites contained in mistletoe and twigs of parasitized host plants. Caution should therefore be exercised when selecting the species of mistletoe and parasitized host plant to use or prescribe for treatment of ailments. Finally, the basic aspects of mistletoe and host plant ecology including how they speciate should be investigated.

\section{REFERENCES}

1. Norton DA, Carpenter MA. Mistletoe as parasites: host specificity and speciation. Trends in Ecology and Evolution. 1998; 13: 101-105

2. Okubamichael DY, Griffiths ME, Ward D. Host specificity in parasitic plants- perspectives from mistletoes. AoB PLANTS 2016; 8 plw069; doi: 10.1093/aobpla/plw069

3. Visser J. South African parasitic flowering plants. Juta, Cape Town, South Africa; 1981.

4. Tomilov AA, Tomilova NB, Abdallah L and Yoder JI. Localized hormone fluxes and early haustorium development in the hemiparasitic plant Triphysaria versicolor. Plant physiology. 2005; 138: 1469-1480.

5. Kuijt J. The Biology of Parasitic Flowering Plants. University of California Press, Berkeley, 1969. xvi $+248 p$

6. Calder DM, Bernhardt P. (eds.). The Biology of Mistletoes. Sydney, Australia: Academic. 1983; 348. pp 1-18.

7. Nickrent DL and Musselman LJ. Parasitic flowering plants. American Photo pathological Society. APSnet Education Center, the Plant Health Instructor web publication. The Plant Health Instructor. 2004. DOI: 10.1094/PHI-I-2004-0330-01.

8. Polhill R, Wiens D. Mistletoes of Africa. Royal Botanic Gardens Kew, Richmond, UK. 1998.

9. Fadini RF. Non-overlap of hosts used by three congeneric and sympatric Loranthaceous mistletoe species in an Amazonian savanna: host generation to extreme specialization. Aota Botanica Brasilica. 2011; 25: 337-345.

10. Tizhe TD, Alonge SO and Aliyu RE. Mistletoe presence on five tree species of Samaru area, Nigeria. African Journal of Plant Science. 2016; 10 (1):16-22. DOI: 10.5897/AJPS2015.1335

11. Monteiro RF, Martins RP, Yamamoto K. Host specificity and seed dispersal of Psittacanthus robustus ( Loranthaceae) in South-East Brazil. Journal of Tropical Ecology. 1992;8:307-314.

12. Ishizu T, Winarno, Tsujino E, Monta T \& Shibuya H. Indonesian Medicinal Plants. XXIV. Stereochemical structure of Perseitol-K complex isolated from the leaves of Scurrula fusca ( Loranthaceae), Chem. Pharm. Bull. 2002; 50(4): 489-492.

13. Osadebe PO, Okide GB, Akabogu IC. Study on anti-diabetic activities of crude methanolic extracts of Loranthus micranthus (Linn.) sourced 
from different host trees. J Ethnopharmacol. 2004; 95 (2-3): 133-138.

14. Adodo A. Mistletoe: The wonder herb. The Nation Newspaper. Pax Herbal Clinic Research Laboratories, St. Benedict Monastery, Ewu, Edo State. 2014

15. Adesina SK, IIloh HC, Johnny II, Jacobs IE. African mistletoes (Loranthaceae); Ethnopharmacology, Chemistry and Medicinal values. African Journal of Traditional, Complementary and Alternative Medicines (AJTCAM). 2013; 10(4):161-170.

16. Dibong SD, Engone ONL, Din N, Priso RJ, Taffouo VD, Fankem H, Salle G, Missoup AD, Boussim IJ, Amougou A. An assessment on the uses of Loranthaceae in ethnopharmacology in Cameroon; A case study made in Logbessou, North of Douala. Journal of Medicinal Plants Research. 2009; 30:1839-1844.

17. Fukunaga T, Nishiya K, Kajikawa I, Takeya K, Hokawa H. Studies on the constituents of Japanese mistletoes from different host trees and their antimicrobial and hypotensive properties. Chem. Pharm. Bull. (Tokyo). 1989; 37(6):1543-1546.

18. Amico GC, Vidal-Russell R, and Nickrent DL. Phylogenetic relationships and ecological speciation in the mistletoe Tristerix (Loranthaceae): the influence of pollinators, dispersers and hosts. American Journal of Botany. 2007; 94:558-567.

19. Yoder J I. Parasitic plant responses to host plant signals: a model for subterranean plant-plant interactions. Current Opinion in Plant Biology. 1999; 2:65-70.

20. Mathiasen RL, Nickrent DL, Shaw DC and Watson DM. Mistletoes: pathology, systematics, ecology and management. Plant Disease. 2008; 92:988-1006

21. Wahab OM, Ayodele AE and Moody JO. TLC phytochemical screening in some Nigerian Loranthaceae. Journal of Pharmacognosy and Phytotherapy. 2010; 2(5):64-70.

22. Nina A, Taufik F, and Akhmad D. Bioactivities evaluation of Indonesian mistletoe (Dendrophthoe pentandra (L.)Miq.) leaves extracts. Indonesian Institute of Sciences, Tangerang Selatan, Indonesia. 2012.

23. Moghadamtousi SZ, Hajrezaei M, Abdul KH and Zandi K. Loranthus micranthus Linn: Biological Activities and Phytochemistry. EvidenceBased Complementary and Alternative Medicine. 2013, Article ID 273712, 9p. http://dx.doi.org/10.1155/2013/273712

24. Osadebe PO, Omeje EO, Uzor PF, David EK and Obiorah DC. "Seasonal variation for the antidiabetic activity of Loranthus micranthus methanol extract," Asian Pacific Journal of Tropical Medicine. 2010; 3(3):196-199.

25. Osadebe PO and Ukwueze SE. "A comparative study of the phytochemical and anti-microbial properties of the Eastern Nigerian specie of African Mistletoe (Loranthus micranthus) sourced fromdifferent host trees," Bio-Research. 2004; 2(1):18-23.

26. Osadebe PO, Dieke CA and Okoye FBC. "A study of the seasonal variation in the antimicrobial constituents of the leaves of Loranthus micranthus sourced from Percia americana," Planta Medica. 2007; 73: 205-210.

27. Isikhuemen EM and Bamawo, OP. Effect of forest understorey shade on vegetative growth and development of Thaumatococcus daniellii, (Benn.) Benth. Nigerian Journal of Forestry. 2013; 43 (1 \& 2): 45 - 52.

28. Odjugo PA, Enaruvbe GO, Isibor HO. Geospatial approach to spatiotemporal pattern of urban growth in Benin City, Nigeria. African Journal of Environmental Science and Technology. 2015; 9 (3):166-175.

29. Edeoga HO, Okwu DE and Mbaibie BO. Phytochemical constituents of some Nigerian medicinal plants. African Journal of Biotechnology. 2005; 4 (7):685 - 688 .

30. Boham BA, Kocipai-Abyazan R. Flavonoids and condensed tannins from leaves of Hawaiin Vaccinium vaticulatum and Vaccinium calycynium. Pacific Science. 1994; 48:458-463.

31. Van-Burden TP, Robinson T. The biochemistry of alkaloids, $2^{\text {nd }}$ edition. Springer, Heidelberg, New York. 1981

32. Obadoni BO, Ochuko PO. Phytochemical studies and comparative efficacy of the crude extract of some homeostatic plants in Edo and Delta states of Nigeria. Global Journal of Pure and Applied Science. 2001; 8:203-208.

33. Soladoye MO, Chukwuma EC. Quantitative phytochemical profile of the leaves of Cissus populnea Guill. \& Perr. (Vitaceae) - an important medicinal plant in central Nigeria. Archives of Applied Science Research. 2012; 4 (1):200-206.

34. Piero NM, Joan MN, Richard OO, Jalemba MA, Omwoyo OR. Determination of cyanogenic compounds content in transgenic acyanogenic Kenyan cassava (Manihot esculenta Crantz) genotypes: Linking molecular analysis to biochemical analysis. Journal of
Analytical and Bioanalytical Techniques. 2015; 6:264-271.

35. Overfield D, Riches C, Samoah AM, Sarkodie O, Baah F. A farming system analysis of the mistletoeproblem in Ghanaian Cocoa. Cocoa Grower's Bulletin. 1998; 51:42-50.

36. Dibong SD, Din N, Priso RJ, Taffouo VD, Fankem H, Salle G and Amougou A. Parasitism of host trees by the Loranthaceae in the region of Douala (Cameroon). African Journal of Environmental Science and Technology. 2008; 2(11):371-378.

37. Asare-Bediako E, Addo-Quaye AA, Tetteh, J. P, Buah JN, Van Der Puije GC, Acheampong RA. Prevalence of mistletoe on citrus trees in the Abura-Asebu-Kwamankese district of the central region of Ghana. International Journal of Scientific \& Technology Research. 2013; 2(7):122-127.

38. Norton DA, de Lange PJD. Host specificity in parasitic mistletoe (Loranthaceae) in New Zealand, Functional Ecology. 1999; 13:101-105.

39. Barlow BA, Wiens D. Host-parasite resemblance in Australian mistletoe: the case for cryptic mimicry. Evolution. 1997; 31:69-84.

40. Downey PO. An inventory of host species of each aerial mistletoe species (Loranthaceae and Viscaceae) in Australia. Cunninghamia. 1997; 5:685-720.

41. Rahmad ZB, Addo-Fordjour P, Asyrafl P and Rosely NFN. Mistletoe abundance, distribution and associations with trees along roadsides in Penang. Tropical Ecology. 2014; 55(2):255-262.

42. Buen LL and Ornelas JF. Frugivorous birds, host selection and the mistletoe Psittacanthus schiedanus in central Veracruz, Mexico. Journal of Tropical Ecology. 1999; 15:329-340.

43. Roxburgh $L$ and Nicolson SW. Patterns of host use in two African mistletoes: the importance of mistletoe-host compatibility and avian disperser behavior. Functional Ecology. 2005: 19:865-873.

44. Burkill HM. The useful plants of West Tropical Africa. Royal Botanical Gardens, Kew: 1985; pp 548-560.

45. Pattanayak SP, Sunita P. Wound healing, anti-microbial and antioxidant potential of Dentrophthoe falcate (L.f) Ettingsh. Journal of Ethnopharmacology. 2008; 120:241-247.

46. Didier DS, Laurier EON, Din N, Jules PR, Victor T, Henri F, Georges S and Akoa A. Artificial infestations of Tapinanthus ogowensis (Engler) Danser (Loranthaceae) on three host species in the Logbessou Plateau (Douala, Cameroon). Africa Journal of Biotechnology. 2009; 8(6): 1044-1051.

47. Buen LL, Ornelas JF and García-Franco JG. Mistletoe infection of trees located at fragmented forest edges in the cloud forests of Central Veracruz, Mexico. Forest Ecology and Management. 2002; 164:293-302

48. Overton JM. Dispersal and infection in mistletoe metapopulations. Journal of Ecology. 1994; 82:711-723.

49. Clay K, Dement D, Rejmanek M. Experimental evidence for host races in mistletoe (Phoradendron tomentosum). American Journal of Botany. 1985; 72:1225-1231.

50. Adodo A. Nature Power: A Christian Approach to Herbal Medicine. St. Benedict Monastery, Ewu, Edo State, Nigeria. 2002. 207p

51. Preston AL, An M, Watson DM. Chemical Profile differences in Endemic Parasitic Weeds: a Study of host-parasite chemical Profiles in Selected Mistletoe and Eucalyptus species. 17th Australian Weed Conference; 2010

52. Ibrahim JA, Egharevba HO, Iliya I, Tarfa F and Ayodele EA. Chemical Profiles as Chemotaxonomic tools for Loranthaceae in Nigeria. African Journal of Plant Science. 2014; 8(7):343-352.

53. Dibong SD, Taffouo VD, Ndiang Z, Ngotta B, Mony R, Engone Obiang NL, Din N, Priso JR, Issaka BJ and Amougou A. The study of sodium and potassium distribution in five host species of Phragmanthera capitata (Sprengel) S. Balle in the littoral region of Cameroon. J. Appl. Biosci. 2010; 30:1839-1844.

54. Williams SS. Mistletoe. Garden Line Porpouri Miscellaneous/ Mistletoe. 1990. Available from: Http://www.gardenline.usask.ca/ misc/mistletoe.html

55. Apori SO, Castro FB, Shand WJ and Orskov ER. Chemica composition, in saccodegradation and in vitro gas production of some Ghanaian browse plants. Animal Feed Science and Technology. 1998; 76(1-2):129-137.

56. Abo KA, Ogunleye VO and Ashidi JS. Antimicrobial potential of Spondias mombin, Croton zambesicus and Zygotritonia crocea. Phytotherapy Research. 1999; 13:494-497

57. Caraballo A, Caraballo B and Rodriguez-Acosta A. Preliminary 
assessment of medicinal plants used as antimalarials in the SouthEastern Venezuelan Amazon. Revista-da-Soci edade-Brasileira-deMedicina-Tropical. 2004; 37(2):186 - 188.

58. Ayoka AO, Akomolafe RO, Akinsomisoye OS and Ukponmwan OE. Medicinal and Economic Value of Spondias mombin. African Journal of Biomedical Research. 2008; 1:129 - 136.

59. Akubue PI, Mittal GC and Aguwa CN. Preliminary pharmacological study of some Nigerian medicinal plants. Journal of Ethnopharmacology. 1983; 8:53-63.

60. Offiah VN and Anyanwu II. Abortifacient activity of an aqueous extract of Spondias mombin leaves. Journal of Ethnopharmacology. 1989; 26:317-320

61. Ayoka AO, Akomolafe RO, Iwalewa EO, Akanmu MA and Ukponmwan OE. Sedative, antiepileptic and antipsychotic effects of Spondias mombin L. (Anacardiacaea) in mice and rats. Journal of Ethnopharmacology. 2006; 103:166-175.

62. Corthout J, Pieters LA, Claeys M, Vanden Berghe DA and Viletinck AJ. Antibacterial and molluscicidal phenolic acid from Spondias mombin. Planta Medica. 1994; 60:460-463.

63. Corthout J, Pieters LA, Claeys M., VandenBerghe DA and Viletinck AJ. Antiviral Caffeoyl; Esters from Spondias mombin. Phytochemistry. 1992; 31, 79.

64. Pauly G and Fleury M. Cosmetic containing plant extracts, Official Gazette of US patents and trademark Office Patents. 2002; 1259(3).

65. Ajao AO and Shonukan O. Antibacterial effect of aqueous and alcohol extracts of Spondias mombin and Alchomea cordifolia: 2 local antimicrobial remedies. International Journal of Crude Drug Research. 1985; 23:67-72.

66. Raji Y, Gbadegesin MA, Osonuga OA, Adisa RA, Akinsomisoye OS, Awobajo FO, Kunle-Alabi OT, Esegbue Peters, P. R. C., Osonuga I. O.,Lamidi A. F. Reproductive, Haematologic and Biochemical profiles of male rats treated with aqueous extract of Spondias mombin bark. International Journal of Pharmacology. 2006; 2 (1): 126 - 130

67. Ademola IO, Fagbemi BO, and Idowu SO. Anthelmintic activity of extract of Spondias mombin against gastrointestinal nematodes of sheep; studies in vitro and in vivo. Tropical Animal Health and Production. 2005; 37 (3), $223-235$

68. Abad MJ, Bermejo P, Carretero E and Martinez-Acitores C. Antiinflammatory activity of some medical plant extracts from Venezuela. Journal of Ethnopharmacology. 1996; 55 (1), 63 - 68.

69. Ayoka AO, Akomolafe RO, Iwalewa EO and Ukponmwan O. E. Studies on the anxiolyticeffects of Spondias mombin L. (Anacardicaea) extracts. African Journal of Traditional, Complementary and Alternative Medicine. 2005; 2 (2), 153 - 165.

70. Aguwa CN. and Lawal AM. Pharmacologic studies on the active principles of Calliandra portoricensis leaf extracts. J Ethnopharmacol. 1988; 22(1):63-71.

71. Orishadipe AT, Okogun JI, Mishelia E. Gas chromatographymass spectrometry analysis of the hexane extract of Calliandra portoricensis and its antimicrobial activity. Afr J Pure Appl Chem. 2010; 4(7): 131-134

72. Onyeama HP, Ahmed MS, Ofemile PY, Ibekwe HA, Nwankpa P. Effects of Calliandra portoricensis extracts on the lipid profile of wistar rats challenged with venom of carpet viper. J Med Med Sci. 2012; 3(10):674-678

73. Amujoyegbe OO, Agbedahunsi JM, Akanmu MA. Antisickling Properties of Two Calliandra Species: C. portoricensis and C. haematocephala (Fabaceae). Eur J Med PI. 2014; 4(2):206.

74. Akah PA, Nwambie Al. Nigerian plants with anti-convulsant property. Fitoterapia. 1993; 64(1):42-44.

75. El-ghani M. Traditional medicinal plants of Nigeria: an overview. Agriculture and Biology Journal of North America, 2016, 2151-7517

76. Adesina SK. Studies on some plants used as anticonvulsant in Amerindian and African traditional plant medicines. Fitoterapia. 1982; 53: $147-162$

77. Agunu A, Abdurahman EM, Shok M, Yusuf SA. Analgesic activity of the roots and leaves extracts of Calliandra portoricensis. Fitoterapia. 2005; 76 (5):442-445.

78. Trease G.E., Evans WC. Pharmacognosy, Edn 11, Bailliere Tindall, 1989. London.

79. Omotayo FO, Omoyeni OA. Phytochemical, anti-nutritive and mineral composition of extracts of leaves of Waltheria Americana L. (syn. W. indica L.) and bark of Okoubaka aubrevillei Pellegr and Normand. Bull Biol. Sci. 2009; 7(1):1-6
80. Bouayad N, Rharrabe K, Lamhamdi M, Nourouti NG and Sayah F. Dietary effects of harmine, a ß-carboline alkaloid, on development, energy reserves and a amylase activity of Plodia interpunctella Hübner (Lepidoptera: Pyralidae). Saudi Journal of Biological Sciences. 2011; 19(1): 73-80.

81. Reus GZ, Stringani RB, Goncalves CL, Scaini G, Carvalho-Silva M, and Jeremias GC. Administration of harmine and imipramine alters creatine kinase and mitochondrial respiratory chain activities in the rat brain. Depress Res Treat 2012: 397-987.

82. Trease GE, Evans WC. Pharmacognosy, Edition 14. Elsevier, 2005; New Delhi, India.

83. Madziga HA, Sanni S and Sandabe UK. Phytochemical and Elemental Analysis of Acalypha wilkesiana Leaf. Journal of American Science. 2010; 6 (11): 510-514.

84. Krapcho A.P., Petry M.E., Getahun Z., Landi J.J., Stallman J., Polsenberg J.F., Gallagher C.E., Maresch M.J., Hacker M.P., Giuliani F.C., Beggiolin G, Pezzoni G., Menta E., Manzotti C, Olivia A., Spinelli S., and Tognella S. A novel class of chromophore modified antitumor anthracene-9, 10-diones: synthesis and antitumor evaluations. Journal of Medical Chemistry, 1994; 37(6): 828-837.

85. Winter RW, Kenneth AC, Linda LJ, Marina I, David JH, Micheal KR Potentiation of the antimalarial agent rufigallol. Antimicrobial Agents and Chemotherapy, 1996; 40:1408-1411.

86. Okwu D.E., Josiah C. Evaluation of chemical composition of two Nigerian medicinal plants. African Journal of Biotechnology; 2006); 5(4): 357-361.

87. Yamamoto Y., Gaynor RB. Therapeutic potential of inhibition of the NF.Kb pathway in the treatment of inflammation and cancer. Journal of Clinical Investigation. 2001; 107(2): 135-142.

88. Cazarolli LH, Zanatta L, Alberton EH, Figueiredo MS, Folador P, Damazio RG, Pizzolatti MG, and Silva FR. Flavonoids: Prospective drug candidates. Mini-Reviews in Medicinal Chemistry, 2008; 8(13):14291440.

89. Halilu ME, AhmedA, Ugwah-Oguejofor, CJ, and Ibrahim G. Comparative Pharmacognostic and Anti-bacterial Studies of Moringa oleifera leaf, flower and its mistletoe (Tapinanthus gloiferus). Nigerian Journal of Pharmaceutical and Biomedical Research, 2016; 1 (1): 22 - 27.

90. Mohammed S. Anticancer agents from medicinal plants. Bangladesh Journal of Pharmacology. 2006; 1 : 35-41.

91. Bagchi D, Garg A, Krohn RL, Bagchi M, Bagchi DJ, Balmoori J. and Stohs SJ. Protective effects of grape seed proanthocyanidins and selected antioxidants against TPA-induced hepatic and brain lipid peroxidation and DNA fragmentation, and peritoneal macrophage activation in mice. General Pharmacology. 1998; 30: 771-776.

92. Ye X, Krohn R. and Liu W. The cytoxic effects of a novel IH636 grape seed proanthocyanidin extract on cultural human cancer cells. Mol Cell Biochemistry. 1999; 196:99.

93. Uji T, Sunrayo Rachman E.. Keanekavagaman Jenis Benalu Parasit Pada Tanaman Koleski Di Kebun Raya Eka Karya, Bali. Berki. Penel. Hayati. 2007; 13:1-5

94. Siddiqui S, Verma A, Rather AA, Jabeen F, Meghvansi MK. Preliminary phytochemicals analysis of some important medicinal and aromatic plants. Advanced in Biological Research. (2009); 3(5-6): 188-195.

95. Dixon RA, Sumner LW. Legume natural products: Understanding and manipulating complex pathways for human and animal health. Plant Physiology. 2003; 131:878-885.

96. Soetan KO, Oyekunle MA, Aiyelaagba $\mathrm{OO}$ and Fafunso MA. Evaluation of the antimicrobial activity of saponins extract of Sorghum bicolor L. Moench. African Journal Biotechnology. 2006; 5: 2405-2407.

97. Asami, Danny K. Comparison of the total phenolic and ascorbic acid content of freeze-dried and air-dried marionberry, strawberry, and corn grown using conventional, organic and sustainable agricultural practices. Journal of Agricultural and Food Chemistry, 2003; 51(5): 1237-1241.

98. Khanna SK, Viswanathan PN, Krishnan PS, Sanwal GG. Extraction of total phenolics in the presence of reducing agents. Phytochemistry. 1968; (9): 1513-1517.

99. Salatino A, Kraus JE, Salatino MLF. Contents of tannins and their histological localization in young and adult parts of Struthanthus vulgaris Mart. (Loranthaceae). Annals of Botany. 1993; 72: 409-414.

100. Islamiyat FB, Moruf OO, Sulaiman AO and Adeladun SA. A review of cyanogenic glycosides in edible plants. Toxicology-New Aspects to This Scientific Conundrum. 2016; 8: 180-186.

101. Rosling $\mathrm{H}$. Measuring effects in humans of dietary cyanide exposure from cassava. Acta Hortic. 1994; 375: 271-283. 